\title{
PENGUATAN EKONOMI KREATIF KELUARGA KESENIAN JARANAN DAN BANTENGAN TRAH KANJURUHAN KELURAHAN TLOGOMAS KOTA MALANG
}

\author{
Sri Andriani, Faridatus Suhadak, Dwi Hidayatul Firdaus \\ UIN Maulana Malik Ibrahim Malang \\ E-mail: sriandrianiuin@gmail.com,faridatus.syuhada@yahoo.com, \\ elfirdausy2015@gmail.com
}

\begin{abstract}
Mentoring of society base on economics and business science have formed a group in posdaya, posdaya which became example is posdaya of As-syuro village Tlogomas Malang City. The society that developed art actually come from the Assembly of worshipers tahlil and tiba'an. They have been able to operate profesionally their tools, or in other words just do activities as a hobby and do friendship (Silaturahim) between pilgrims (jama'ah). So the common condition need the change of managerial ability. There is no handling expected can increase family income, and ultimately become superior product in Tlogomas and also can create a creative economy that also became the goal of the current Administration (President of Joko widodo). So. All condition commonly need change of managerial ability.

Pendampingan masyarakat berbasis ilmu ekonomi dan bisnis yang telah membentuk kelompok dalam pos daya, maka pos daya yang yang menjadi dampingan adalah pos daya As-Syuro Kelurahan Tlogomas Kota Malang. Masyarakat yang mengembangkan kesenian ini sebenarnya bermula dari perkumpulan jamaah tahlil dan tiba'an. Mereka sudah mampu mengoperasikan secara profesioanal alat-alat pertunjukannya, atau dengan kata lain hanya melakukan kegiatan sebatas hobi dan melakukan silaturahim antar jamaah. Belum ada penanganan yang diharapkan memperoleh pendapatan yang dapat menambah pendapatan keluarga, dan pada akhirnya menjadi produk ungulan Kelurahan Tlogomas sekaligus dapat menciptakan ekonomi kreatif yang juga menjadi tujuan pemerintah sekarang (Presiden Joko widodo). Maka kondisi yang ada secara umum memerlukan pembenahan kemampuan manajerial.
\end{abstract}

Keywords: ekonomi kreatif, bantengan

\section{Pendahuluan}

Perekonomian Indonesia akan memiliki fudamental yang kuat jika ekonomi kerakyatan telah menjadi pelaku utama yang produktif dan berdaya saing tinggi. Salah satu faktor pembangunan ekonomi kerakyatan yang memegang peranan penting dan strategis adalah pengembngan Usaha Mikro, Kecil dan Menengah (UMKM). Pengalaman menunjukan bahwa usaha mikro, kecil dan menengah memiliki ketangguhan terhadap goncangan perekonomian global. Disamping itu usaha mikro, kecil dan menengah juga memiliki kemampuan menyerap tenaga kerja yang besar, membuka peluang berusaha dan dapat mewujudkan peningkatan dan pemerataan pendapatan masyrakat. Dengan UMKM yang kuat maka strukutur ekonomi menjadi kokoh, yang berperan besar dalam dalam peningkatan ekspor dan pengendalian impor, serta tumbuh dan berkembang pada basis kemampuan diri sendiri. 
Di Indonesia hal itu bisa dilihat dari jumlah unit usahanya yang sangat banyak di semua sektor ekonomi dan kontribusinya yang besar terhadap penciptaan lapangan pekerjaan dan sumber pendapatan, khususnya di daerah pedesaan dan bagi rumah tangga berpendapatan rendah. Peran UMKM di Indonesia yaitu (1) UKM pemain utama dalam kegiatan ekonomi di Indonesia, (2) Penyedia kesempatan kerja, (3) Pemain penting dalam pengembangan ekonomi lokal dan pengembangan masyarakat, (4) Pencipta pasar dan inovasi melalui fleksibilitas dan sensitivitasnya serta keterkaitan dinamis antar kegiatan perusahaan, dan (5) memberikan kontribusi terhadap peningkatan ekspor non migas. Oleh karena itu, sektor UMKM telah dipromosikan dan dijadikan sebagai agenda utama pembangunan ekonomi Indonesia. UMKM telah terbukti tangguh ketika terjadi krisis ekonomi 1998, dimana hanya sektor UMKM lah yang bertahan dari kolapsnya ekonomi, sementara sektor yang lebih besar justru tumbang oleh krisis. UMKM terbukti tahan terhadap krisis dan mampu survive karena, pertama, tidak memiliki utang luar negeri, kedua tidak banyak utang diperbankan karena modal tidak terlalu besar, dan ketiga menggunakan input lokal dan yang terakhir berorientasi ekspor.

UMKM 60\% tersebar di pulau jawa (DKI Jakarta, Jawa Timur, Jawa Barat, dan Jawa tengah), DKI Jakarta memiliki unit UKM terbanyak sekitar 13,7 persen lalu disusul oleh Jawa Timur yang memiliki sekitar 12,5 persen, kemudian Jawa Barat dengan proporsi jumlah UKM sebanyak 11,5 persen. Hal tersebut membuktikan bahwa UKM masih terkonsentrasi di Jawa. Tingginya unit UKM di Jawa Timur sejalan dengan pertumbuhan ekonomi Jawa Timur yang juga tertinggi. Pola pertumbuhan ekonomi dilihat dari sisi kewilayahan di Jawa Timur menunjukkan adanya wilayah yang sangat maju dan wilayah yang masih tertinggal. Dengan kata lain menunjukkan terjadinya ketimpangan. Pertumbuhan ekonomi yang tinggi terpusat di perkotaan seperti Kota Surabaya dan sekitarnya (Sidoarjo dan Gresik), serta Kota Malang dan Kabupaten Malang. Kota-kota tersebut merupakan pusat aktivitas ekonomi di Jawa Timur dengan kontribusi sebesar 50 persen terhadap total ekonomi Jawa Timur pada tahun 2010 (World Bank: 2011). Lebih khusus lagi, tahun 2010 angkatan kerja di Jawa Timur sekitar 20 juta jiwa dan $40 \%$ tenaga kerja bekerja di UMKM. Rata-rata tiga tahunan terakhir pertumbuhan tenaga kerja di UMKM yang terbanyak terdapat di Kabupaten Malang sekitar 500.000 tenaga kerja. Kemudian di susul dengan Kabupaten Jember sebanyak 450.000 tenaga kerja dan diikuti oleh kabupaten Sumenep, Surabaya dan Lamongan. Sedangkan wilayah dengan distribusi UMKM terendah terdapat di wilayah Kota Mojokerto sekitar 23.000 tenaga kerja, disusul dengan Kota Pasuruan 26.000 tenaga kerja, kemudian Batu, Blitar dan Probolinggo. Penyerapan tenaga kerja sektor UMKM di Jawa Timur masih belum merata, hanya terkonsentrasi di beberapa wilayah saja dan masih menunjukkan ketimpangan yang tinggi di beberapa wilayah. Tenaga kerja tersebut terseba pada bidang usaha yang terkumpul dalam sentra-sentra usaha Tenaga kerja tersebut terseba pada bidang usaha yang terkumpul dalam sentra-sentra usaha.

Tidak hanya dari sisi tenaga kerja, penyebaran usaha yang yang ada di Jawa Timur diharapkan dapat mendukung program pemerintah dalam pembentukan "Industri Kreatif Indonesia", (Renstra Kementrian Pariwisata dan Ekonomi Krestif Indonesia). Industri kreatif saat ini diyakini dapat memberikan kontribusi bagi perkembangan perekonomian secara signifikan, khususnya fashion dan kerajinan mampu memberikan kontribusi terbesar (Annual Report BI, 2014). Banyak studi telah dilakukan untuk melihat perkembangan serta kiprah sektor industri kreatif dalam perekonomian di dunia, termasuk juga di Indonesia. Perkembangan industri kreatif di Indonesia juga dapat dilihat dari keadaan daerah-daerah di Indonesia baik tingkat provinsi maupun tingkat kota dan kabupaten. Data statistik tahun 2009 menjelaskan bahwa beberapa provinsi dan kota di Indonesia telah memenuhi kriteria digolongkan sebagai provinsi kreatif, seperti provinsi Yogyakarta merupakan 
provinsi dengan jumlah laman industri kreatif terbanyak di Indonesia, yaitu sebanyak 326.000 laman. Selanjutnya pada peringkat ke dua adalah Bali dengan 158.000 laman, serta Jawa Barat dan Jawa Tengah pada peringkat ketiga dengan 132.000 laman. Hal ini konsisten terhadap kondisi dimana Jogja, Bali dan Bandung merupakan kota-kota yang dapat digolongkan sebagai kota kreatif, sedangkan untuk Malang sendiri berdasarkan penjelasan dari data statistik departemen perindustrian dan perdagangan (2009) masih tergolong bukan kota industri kreatif.

Secara Nasional sektor industri kreatif ini merupakan sektor industri yang potensial untuk dikembangkan, karena jika dilihat dari sumber daya yang dimiliki oleh bangsa Indonesia, kreativitas masyarakat Indonesia dapat disejajarkan dengan bangsa-bangsa lainnya di dunia. Hal ini terbukti dengan banyak sekali karya anak bangsa yang diakui oleh komunitas internasional. Menurut World Economic Forum (2009) Indonesia tercatat menempati peringkat ke-43 di Economic Creativity Index Ranking.

Industri kreatif potensial untuk dikembangkan mengingat industri ini memiliki sumber daya yang sifatnya tidak terbatas, yaitu berbasis pada intelektualitas sumber daya manusia yang dimiliki. Karakteristik industri ini sangatlah berbeda dengan karakteristik industri yang sarat akan kebutuhan sumber daya alam sebagai bahan dasar pokok dalam proses produksinya, sehingga membutuhkan perlakuan/kebijakan yang berbeda dari sektor industri lainnya. Hingga saat ini, Departemen Perdagangan RI (2007) telah mencatat 15 cakupan kelompok ekonomi kreatif, yaitu meliputi: (1) Jasa Periklanan; (2) Arsitektur; (3) Seni Rupa; (4) Kerajinan; (5) Desain; (6) Mode (fesyen); (7) Film; (8) Musik; (9) Seni Pertunjukan; (10) Penerbitan; (11) Riset dan Pengembangan; (12) Piranti Lunak (Software); (13) Televisi dan Radio; (14) Mainan; dan (15) Video game. Cakupan industri kreatif inilah yang menjadi dasar dalam membuat konsep pengembangan ekonomi kreatif.

Salah satu kelompok ekonomi kreatif adalah kelompok musik islami, jaranan/bantengan yang merupakan kelompok pos daya As-Syuro terdapat di RW.2 Kelurahan Tlogomas Kota Malang Jawa Timur. Kelompok musik islami, jaranan.bantengan yang ada telah diwarisi secara turun-temurun, bahkan sejak Kelurahan Tlogomas masih menjadi Desa Tlogomas (Kerajaan Kanjuruhan). Berkembangnya kelompok-kelompok ini diawali dari kebudayaan panen hasil bumi di daerah Guyangan dan Watugong (Sekarang Tlogomas RW 2 dan 3). Berjalannya waktu sampai sekarang sudah berkembang, disetiap RW memiliki kelompok kesenian baik kesenian islami (gambus, terbang jidor) yang dibina oleh Cak Rokhim, musik perkusion dari barang bekas (tong, kaleng, bambu) binaan bapak Ruskandar Rt.4 Rw.2, musik patrol (bantu dan kentongan) binaan bapak Djuri Rt.6 Rw.2, jaranan/bantengan (kuda lumping) dibina oleh Bapak Sangat dan wayang kulit dengan dalang Ardi Purboantono RW.6 yang tergabung dalam pos daya Sapu Jagad Kelurahan Tlogomas.

Kegiatan mereka masih sebatas berlatih, iuran anggota untuk membeli alat dan tampil dalam acara bersih desa, bari'an dan karnaval yang bersifat lokal, padahal potensi untuk dikembangkan dalam usaha kreatif sangat memungkinkan, yang sudah berjalan adalah kesenian wayang kulit, namun manajemen yang dilakukan masih sebatas kekeluargaan dan kepercayaan saja sehingga belum bisa mengangkat perekonomian panjak-panjaknya (pemain) dari kelompok-kelompok tersebut. Meskipun mereka melakukan kegiatan karena hobi, kelompok kesenian ini pernah berjaya ditahun 80-an.

Meskipun Kelurahan Tlogomas telah memenangkan lomba administrasi kelurahan tingkat nasional, namun kehidupan masyarakatnya $60 \%$ masih berubah buruh tani, tukang bangunan, pembantu rumah tangga, buruh usaha kecil (keramik), dan $40 \%$ pendatang pegawai negeri sipil, ABRI dan pegawai swasta. Dengan kata lain masih masih banyak penduduk pra sejahtera dan miskin (data BKM Kelurahan Tlogomas).

Namun demikian, walaupun masyarakat Tlogomas sudah menjadi perkotaan namun perekonomiannya masih sedang, kemampuan IPTEK yang rendah, penanganan manajerial 
yang lebih pada manajemen keluarga (tanpa memerhitungkan harga keluarga dan usaha). Kondisi ini menyebabkan hasil yang diperoleh dari industrinya hanya mampu untuk kebutuhan pokok keluarga, belum bisa melakukan kegiatan ekspansi, membuka pasar baru, sehingga pendapatan yang diperoleh masih menjadi pendapatan yang sama dengan masyarakat sekitar yang bekerja menjadi petani. Padahal potensi kesenian dan musik masyarakat dapat dikembangkan dijadikan usaha yang dapat menambah penghasilan keluarga.

Hal yang manarik adalah dalam kelompok ini adalah fenomena wanita dan anak-anak yang menjadi bagian dari kesenian, namun keberadaan mereka malah menjadi tulang punggung keluarganya, hal inilah yang menyebabkan munculnya fenomena bagi kaum lakilaki diangap hanya kesenangan, hiburan, maka kesenian yang mereka geluti hanya menjadi sesuatu yang diangap senang-senang belaka, yang lebih memprihatinkan adalah saat laki-laki berlatih dan bermain maka minum-minuman keras, berjudi itu sudah menjadi kebutuhan sehingga para pemain laki-laki lebih terkosentrasi terhadap kesenian, sedangkan keperluan keluarga lebih menjadi tanggung jawab perempuan dan anak-anak mereka. Dengan uraian diatas maka permasalahan pokok yang dihadapi oleh wilayah tersebut diantaranya adalah:

1. Bagaimana memberdayakan wanita dan anggota kesenian jaranan/bantengan trah kanjuruan dalam rangaka pembenahan ekonomi keluarga,

2. Bagaimana pengembangan kesenian dapat menjadi penopang ekonomi keluarga dengan pembenhan manajerial.

\section{Alasan Memilih Subyek Pendampingan}

Setiap daerah mempunyai corak pertumbuhan ekonomi yang berbeda dengan daerah lain. Oleh sebab itu perencanaan pembangunan ekonomi suatu daerah pertama-tama perlu mengenali karakter ekonomi, sosial dan fisik daerah itu sendiri, termasuk interaksinya dengan daerah lain. Dengan demikian tidak ada strategi pembangunan ekonomi daerah yang dapat berlaku untuk semua daerah. Namun di pihak lain, dalam menyusun strategi pembangunan ekonomi daerah, baik jangka pendek maupun jangka panjang, pemahaman mengenai teori pertumbuhan ekonomi wilayah, yang dirangkum dari kajian terhadap pola-pola pertumbuhan ekonomi dari berbagai wilayah, merupakan satu faktor yang cukup menentukan kualitas rencana pembangunan ekonomi daerah.

Karena pemberdayaan masyarakat ini berbasis ilmu ekonomi dan bisnis syariah yang telah membentuk kelompok dalam pos daya, maka pos daya yang yang menjadi dampingan adalah pos daya As-Syuro Kelurahan Tlogomas Kota Malang. Masyarakat yang mengembangkan kesenian ini sebenarnya bermula dari perkumpulan jamaah tahlil dan tiba' an, mereka sudah mampu mengoperasikan secara profesioanal alat-alat pertunjukannya, atau dengan kata lain hanya melakukan kegiatan sebatas hobi dan melakukan silaturahim antar jamaah, belum ada penanganan yang diharapkan memperoleh pendapatan yang dapat menambah pendapatan keluarga, dan pada akhirnya menjadi produk ungulan Kelurahan Tlogomas sekaligus dapat menciptakan ekonomi kreatif yang juga menjadi tujuan pemerintah sekarang (Presiden Joko widodo) maka kondisi yang ada secara umum memerlukan pembenahan kemampuan manajerial.

Pembina, penasehat dan anggotanya yang menjadi kelompok kesenian adalah takmir mushola dan Masjid yang ada di RW.2 Kelurahan Tlogomas. Selain itu pada pertunjukanperunjukkan yang dilakukan terselip dakwah-dakwah yang dianggap dapat menginspirasi masyarakat. Hal ini tampak pada kesiapan yang diakukan dari kedisiplinan, lirik-lirik gamelan, mocopat, dan wayangan pasti tersirat dakwahnya, harapannya dapat membantu dalam mengkondisikan dan mengurangi kegiatan-kegiatan maksisat yang dilakukan di RW.2 Kelurahan Tlogomas, seperti: mabuk-mabukkan yang dilakukan pada saat pemain jaranan/bantenan akan tampil dengan harapan kelihatan kalap pada saat beratraksi (beberapa 
kasus meninggal karena over dosis minuman oplosan), padahal ada kesenian yang tidak harus kalap, sabung ayam, makan-makanan haram (babi, anjing)

Alasan dampingan selain kondisi masyarakat yang ada, kemapuan masyarkat dalam mengembangkan kesenian, pemain dan pembinaanya yang ada di daerah ini adalah takmir masjid (Pak Djuri, Pak Ketang, Pak Ardi, Pak Rusliansyah, Cak Rokhim, Agus Sucipto, Toni urifan, dan bu cipto dan lain-lain). Selain itu kelompok kesenian ludruk dan gamelan di tahun 80-an pernah megalami masa keemasan artinya dapat menjadi mata pencaharian Bapak Sangat), sampai sekarang kesenian-kesenian ini masih banyak mendapatkan tawaran untuk tampil dalam pertunjukkan-pertujukkan seperti tampil di stasiun televisi tertentu namun tidak ada kontrak perjanjiannya dan dana yang diberikan sifatnya hanya seperti uang saku.

Yang menjadi pertimbangan lebih utama adalah para bapak hanya menjalanan kegiatan seni ini menjadi hobi sedangkan pemenuhan ekonomi lebh mengutamakan pada istri dan anak-anaknya, sesuai dengan data yang kami ambil di lapangan ada 80\% perempuan yang bekerja penuh waktu untuk memenuhi kebutuhan keluarganya (sebagai buruh tani, pembantu rumah tangga, penjaga toko, penjaga salon, jualan sayuran, jualan makanan, panjak kesenian, penyanyi karaoke). Berdasarkan ground research yang dilakukan (andriani, 2014) daerah guyangan menjadi salah satu penduduk yang masih agraris, artinya mengandalkan pertanian (tomat, cabe, jamur, jeruk), Namun demikian disaat hasil pertanian murah dan kesenian hanya menjadi hobi maka menimbulkan permasalahan yang kompleks yaitu tingkat kemaksiatan (minum-minuman, judi) menjadi biasa dan akhirnya perempuan dan anak-anak semakin dituntut untuk menopang ekonomi keluarga.

\section{Kondisi Dampingan Saat Ini}

Di setiap wilayah berpenduduk selalu terjadi kegiatan pembangunan, namun ada beberapa wilayah yang pembangunannya berjalan di tempat atau bahkan berhenti sama sekali, dan wilayah ini kemudian menjadi wilayah kelas kedua dalam kegiatan ekonomi. Hal ini mengakibatkan penanam modal dan pelaku bisnis keluar dari wilayah tersebut karena wilayah itu dianggap sudah tidak layak lagi untuk dijadikan tempat berusaha. Akibatnya laju pertumbuhan ekonomi wilayah itu menjadi semakin lambat. Kegiatan ekonomi yang menarik tentunya tidak lepas dari ciri khas daerah tersebut, dalam mengembangkan kegiatan ekonomi, sosial dan budayanya.

Kelurahan Tlogomas merupakan salah satu Kelurahan di Kota Malang yang mempunyai sejarah budaya kerajaan yaitu Kanjuruhan, maka dalam kehiduan sehari-hari daerah ini sangat kental dengan kehidupan yang mengembangkan budaya-budaya seperti bantengan, jaranan, suroan, bersih desa, ludruk, wayang kulit. Dari keberadaan kesenian yang ada menjadi menarik untuk diteliti lebih jauh yaitu tentang kesenian jaranan dan bantengan di RW.2 Kelurahan Tlogmas. Yang menjadi menarik adalah keberadaan pemain dan keluarga pemain sangat mendewakan kesenian dalam kehidupan sehari-hari, sehinga saat laki-laki memainkan kesenian jaranan dan bantengan yang sudah menjadi arisan rutin untuk melakuan gebyar tampilan, maka saat itu pula segala perekonoian keluarga dan kondisi masyarakat mulai berkembang dan ikut berkembang. Hal yang menjadi pemikiran adalah saat mereka memainkan kesenian jaran dan bantengan sudah berubah cara penampilanya, yaitu kalau semula mengedepankan keindahan kesenian, namun sekarang dalam penampilan kesenian ini selalu dan seperti keharusan di mulai dengan minum-minuan keras. Hal inilah yang memperburuk perekonomian keluarga, karena saat sebelum pertunjukkan keluarga sudah harus menyediakan minum-minuman keras dan setelah permainan laki-laki atau sebagai kepala keluarga cenderung tidak bisa mencari nafkah untuk keluarga beberapa hari ke depan; akibatnya wanita dan anak-anak merekalah yang harus membantu menopang keluarga dengan bekerja lebih keras. 
Di RW.2 Kelurahan Tlogomas terdapat Kelompok jaranan As-Syuro dan bantengan "Trah Kanjuruan" Anggota sebagaian besar laki-laki dan anak-anak. Mereka rata-rata sudah berkeluaga atau kalaupun belum berkeluarga masih tinggal dengan orang tuanya.

Kesenian bantengan Trah Kanjuruan Kelurahan Tlogomas yang berpusat di RW.2.merupakan kelompok kesenian yang masih eksis dalam megembangkan budaya lokal dan mampu menggerakkan ekonomi kreatif Kelurahan Tlogomas. Dalam 1 kelompok terdiri dari 18 anggota, mereka rutin mengadakan arisan bantengan dan jaranan dengan bergiliran dari daerah ke daerah bahkan diluar trah Kanjuruan untuk menamplkan kesenian masingmasing. Hal ini dilakukan paling sedikit 1 bulan sekali.

Berdasarkan survey awal dari kegiatan yang dilakukan dapat menggerakan masyarakat sebanyak kurang lebih 500 orang. Bergeraknya masyarakat ini dapat mempengaruhi kehidupan perekonomian sisi positifnya adalah masyarakat dapat berdagang di sekitar lokasi pertunjukan, tetapi sisi negatifnya yang adalah minum-minuman keras dan sex bebas serta , memakan makanan yang haram seperti masakan yang terbuat dari bahan dasar daging anjing an babi. Yang menanggung beban lebih besar dari kejadian ini adalah wanita dan anak-anak.

Peran anggota kelompok kesenian dibedakan menjadi 3 kelompok, yaitu pemain kesenian laki-laki, wanita, dan anak-anak sebagai kelompok yang mengembangkan budaya dan menyaluran hobi, serta kelompok keluarga anggota kesenian (penopang perekonomian keluarga) dalam hal ini wanita dan anak-anaknya. Kelompok kesenian yang hanya hobby akan kita dampingi dalam hal penataan manajerial yang belum tertata guna menjadi salah satu setra kesenian yang memberikan nilai ekonomis lebih tinggi untuk masyarakatnya. Sehingga pendapatan yang diperoleh lebih bisa tertata secara manjerial agar menjadi usaha yang professional. Sentra usaha yang sudah ada diharapkan mampu menjalankan entrepreneur dengan manajerial yang professional, Bentuk kegiatan manajerial yang akan dilakukan dengan harapan sentra industrinya menjadi profesional dan memberi nilai tambah ekonomis pada masyarakatnya

Dengan afirmatif research diahrapkan mampu menggali lebih jauh bagaimana keberadaan keseian ini mampu memunculkan wanita dan anak-anak menjadi korban budaya, sehingga dengan melakukan Forum discussion group diharapkan dengan berbudaya (kesenian jaranan dan bantengan) menjadi meningkatkan ekonomi keluarga, cara-cara yang dilakukan yaitu:

a. Pendampingan wanita sebagai korban budaya

b. Pendampingan anak-anak sebagai potensi pengembangan budaya

c. Pendampingan peningatan ekonomi keluarga

d. Pendampingan manajemen keuangan: Sistem pembiayaan, analisa laporan keuangan

Sedangkan kelompok anggota keluarga yang menjadi penopang ekonomi keluarga akan diberikan pelatihan dengan memanfaatan hasil pertanian (kurma tomat dan saos tomat), pemanfaatan lahan (penanaman tanaman organik), pemanfaatan limbah keluarga (pembuatan pupuk cair). Selain itu pemahaman akan fungsi laki-laki, wanita dan anak-anak dalam keluarga menurut islam.

\section{Strategi yang Dilakukan untuk Mencapai Kondisi Harapan}

Dalam rangka menciptakan kemampuan manajerial kesenian dan memberdayakan anggota kesenian untuk peningkatan ekonomi yang lebih baik dan ada kesetaraan antara lakilaki dan perempuan, digunakan metode PAR (Participatory Action Research). Metode ini digunakan untuk mengembangkan, memahamkan, dan memberdayakan anggota kesenian (laki-laki dan perempuan) terhadap:

1. Kelemahn-kelemahan yang dialami dan dimiliki kelompok kesenian dan perekonoman keluarga 
2. Keinginan-keinginan masyarakat untuk mengatasi kekurangan dan kelemahan kelompok kesenian dan perekonoman keluarga

3. Menyusun strategi dan metode untuk memecahkan permasalahan kesenian dan perekonomian keluarga

4. Membantu kelompok kesenian mengatasi, memecahkan, dan menemukan jalan keluarnya

Metode action research ini digunakan untuk tidak membuat masyarakat dampingan sebagai objek, tetapi menjadikannya sebagai subyek penelitian. Masyarakat sendiri yang memahami, menginginkan, dan memecahkan permasalahan yang melilitnya. Posisi peneliti lebih sebagai fasilitator bagi masyarakat untuk mencapai cita-citanya dan memberikan jalan keluar dan merumuskan strategi yang dapat digunakan masyarakat untuk mencari jalan keluar bagi permasalahan mereka. Namun perumusan jalan keluar dan strategi ini tetap melibatkan masyarakat dengan harapan apabila masyarakat mengalami masalah-masalah sosial, mereka bisa memecahkan permasalahan mereka sendiri tanpa bantuan orang lain.

Dengan PAR (Participatory Action Research) ini bermanfaat untuk memfasilitasi dan memotivasi agar masyarakat khususnya UMKM di RW.2 Kelurahan Tlogomas mampu:

1. Mengidentifikasi kelemahan-kelemahan yang dialami dan dimiliki kelompok kesenian

2. Menemukan dan mengenali faktor-faktor yang menyebabkan kelompok kesenian belum berjalan maksimal dan alternatf pemecahannya

3. Menyusun strategi dan metode yang tepat untuk memecahkan permasalahan kelompok kesenian

4. Menyusun rencana aksi berdasarkan prioritas dan keberlanjuan program yang dimiliki kelompok kesenian.

Adapun strategi yang digunakan dalam melakukan action research ini dapat digambarkan sebagai berikut:

\section{Gambar 3.1: Strategi Action Research O'Brien}

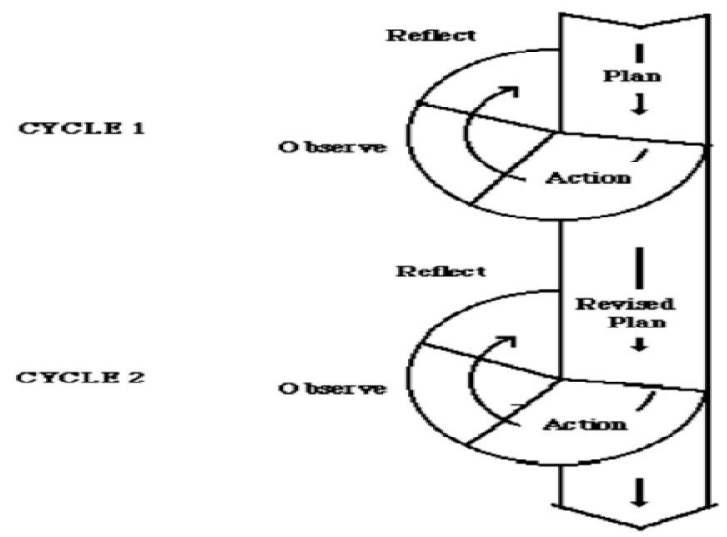

\section{Langkah-Langkah Pendampingan}

Dari gambaran proses action research ini ada 4 tahapan dalam melakukan penelitian, yatu:

1. Perencanaan (plan). Perencanaan ini dilakukan setelah memperhatikan kondisi riil kelompok kesenian dengan peran perempuan yang dominan dengan menggunakan analisis SWOT. Dalam hal menganalisis problematika di kelompok kesenian dan menganalisis dari sisi kekuatan, kelemahan, peluang, dan ancaman yang mungkin terjadi pada keberlangsungan kelompok kesenian ini melibatkan permempuan dan anak-anak di RW 2 Kelurahan Tlogomas. Perencanaan ini meliputi strategi dan metode dalam memecahkan masalah-masalah yang dihadapi oleh kelompok kesenian. Analisis yang digunakan adalah analisis SWOT adalah suatu alat perencanaan strategik yang penting untuk membantu perencana untuk membandingkan kekuatan 
dan kelemahan internal organisasi dengan kesempatan dan ancaman dari external, yaitu dengan analisis SWOT. Pada analisis SWOT memberikan informasi untuk membantu dalam hal mencocokan perusahaan sumber daya dan kemampuan untuk menganalisa kompetitif lingkungan di mana bidang perusahaan itu bergerak. Informasi tersebut dibuat berdasarkan perumusan strategi dan seleksi.

2. Tindakan (Action). Setelah proses perencanaan dilakukan, masyarakat kelompok kesenian mengimplementasikan rencana yang telah dibuat tersebut dengan dibantu dan difasiltasi oleh peneliti

3. Pengamatan (Observe). Pengamatan dilakukan untuk memperhatikan dan menganalisis keberhasilan, kelemehan, dan kekurangan strategi dan metode yang digunakan dalma menyelesaikan masalah-masalah kelompok kesenian. Demikian pula factor-faktor pendukung dan hambatan yang teridentifikasi selama keiatan berlangsung

4. Refleksi (reflect). Usaha-usaha yang telah dilakukan dalam memecahkan masalah-masalah kelompok kesenian tersebut direfleksikan dan dievaluasi, baik kekurangan, kelemahan, keberhasilan strategi dan metode dalam memecahkan masalah-masalah kelompok kesenian tersebut. Refleksi dan evaluasi ini akan berputar terus menuju tapahan yang pertama yaitu perencanaan (plan).

Pengembangan kegiatan industri yang akan dikembangkan dalam kegiatan ini adalah eksisting berupa industri kecil dan industri rumah tangga bagi masyarakat yang belum mempunyai usaha, dan untuk industrial state yang sudah ada akan dikembangkan kemampuan manajerial yang professional. Pelaku industri nantinya akan mempunyai kemampuan entrepreneur sekelas UMKM tapi dengan kemampuan manajerial usaha besar, sehingga hasil yang diperoleh tidak hanya untuk memenuhi kebutuhan pokok saja, namun akan mampu memberikan pengembangan usaha, namun tetap bekerjasama dengan pihak-pihak terkait. Arahan untuk kegiatan manajerial industri adalah mempertahankan dan mengembangkan industri kecil dan industri rumah tangga agar dapat meningkatkan taraf hidup masyarakat yang bergantung pada industri tersebut.

Pengembangan sentra industri ini akan menyerap tenaga kerja lebih banyak di RW.2 Kelurahan Tlogomas Malang Raya. Strategi yang dilakukan untuk mencapai kondisi yang diharapkan adalah dengan melakukan langkah- langkah sebagai berikut :

a. Melakukan focus group discussion (FGD) untuk mengakomodir permasalahan dan kebutuhan yang diperlukan kelompok kesenian

b. Membangun hubungan kemanusiaan antar kelompok kesenian

c. Penentuan agenda riset untuk perubahan manajerial

d. Pemetaan partisipatif wanita, laki-laki, dan anak-anak dalam pengembangan kelompok-kelompok usaha

e. Merumuskan masalah kemanusiaan dan manajerial

f. Menyusun strategi gerakan perubahan manajerial

g. Pengorganisasian

h. Pembekalan keahlihan tambahan anggota (wanita)

i. Melancarkan aksi perubahan

j. Pendampingan manajerial

k. Refleksi

1. Meluaskan skala gerakan dan dukungan

m. Aplikasi manajerial

Bekerja sama dengan pihak-pihak yang terkait untuk mewujudkan hal ini, yaitu LP2M, DMI, PSG, pemuka agama, tokoh masyarakat, dinas perindustrian dan perdagangan, entrepreneur, dan peneliti untuk mewujudkan kondisi yang diharapakan. Para pihak pihak yang terlibat diharapakan dapat memberikan dukungan, masukan, motivasi, peluang dan pendampingan kepada kelompok kesenian khususnya jaranan dan bantengan, sehingga sentra- 
sentra industri yang ada mampu menjalankan usaha dengan manajerial yang professional, pada akhirnya hasil yang diperoleh tidak hanya memenuhi kebutuhn pokok tapi bisa mengembangkan usaha dan mendirikan usaha bagi buruh-buruh kerjanya. Metode pendampingan manajerial yang dilakukan adalah sebagai berikut:

1. Melakukan pendampingan dan menggerakkan partsipasi aktif rakyat mendampingi dalam pengurusan legalitas ijin

2. Melakukan pendampingan dan menggerakkan partisipasi aktif rakyat dalam rangka menghadapi tantangan dalam era globalisasi yang ditandai dengan ketatnya persaingan usaha,

3. Memberikan pelatihan dan bimbingan teknis/pendampingan dengan peran aktif masyarakat dalam hal: pengembangan usaha masyarakat (pembuatan kurma tomat, saos tomat, pupuk cair, tanaman organic)

4. Memberikan pelatihan dan bimbingan teknis/pendampingan dengan peran aktif masyarakat dalam hal: akses pemodalan, pengetahuan dan pengembangan organisasi dan manajemen, pengembangan teknologi, mapping usaha, investarisasi, dan laporan keuangan.

5. Mendampingi dan mewujudkan keinginan masyarakat dalam: membuat, dan mengaplikasikan akses informasi, pemasaran, permodalan, teknologi, manajemen keuangan melalui website,

6. Mendampingi, menyediakan, dan mengkader adanya keterbatasan tim asistensi yang berkualitas dalam hal manajerial

\section{Analisa}

Dunia adalah panggung kausalitas manusia dimana peran manusia sangat bersinergi dengan alam, Tuhan, dan sesamanya . Sesama manusia tak lagi sama sekarang, dominasi lakilaki dan penyetaraan perempuan dengan penindasan menjadi keprihatinan dalam pemahaman peran gender yang sebenarnya. Gender merupakan peran atau tanggung jawab antara perempuan dan laki-laki yang diciptakan oleh lingkungan atau hasil dari konstruksi sosial dan budaya, hal ini membuat gender memiliki peran yang dinamis dan selalu berdampingan dengan perkembangan zaman, gender juga merupakan suatu konsep kultural yang berupaya membuat perbedaan dalam hal peran, prilaku, mentalitas, dan karakteristik emosional antara laki-laki dan perempuan yang berkembang dalam masyarakat. Peran gender dengan kodrat manusia tidaklah sama, kodrat merupakan pemberian Tuhan kepada perempuan maupun lakilaki yang sifatnya tidak dapat dipindah tangankan. Perempuan memiliki kodratnya tersendiri begitu juga dengan laki-laki kodrat perempuan adalah hamil, melahirkan, menyusui, menstruasi, memiliki sel telur dll. Sedangkan kodrat laki-laki adalah memiliki sperma, testis, dll. Sedangkan peran gender adalah tanggung jawab yang bisa dilakukan oleh laki-laki maupun perempuan. Sampai saat ini masyarakat Indonesia masih menafikkan peran gender yang sebenarnya, mereka beranggapan bahwa laki-laki adalah tonggak keberhasilah sebuah sistem dan perempuan Indonesiapun masih ada yang mengaku bahwa kodrat dia dilahirkan adalah untuk memasak, mengasuh anak, dan hal-hal lain yang hanya melibatkan dirinya diwilayah domestik. Patriarkisme tersebut terjadi karena terjangan konstruksi sosial dan budaya telah membentuk pikiran perempuan Indonesia sehingga pola pikir perempuan Indonesia hingga saat ini masih terlalu sexist. Seringkali perempuan diidentikkan dengan mengasuh anak, memasak, menyapu, dan hal-hal lain yang dilakukan diwilayah domestik persepsi tersebut sudah melekat pada semua kalangan masyarakat Indonesia mulai dari yang miskin hingga kaya sebenarnya persepsi sendiri ditimbulkan dari diri individu yang mencoba menggambarkan obyek yang dilihat atau dimengertinya, namun persepsi masyarakat disini telah dipengaruhi oleh kebudayaan dan nilai sosial yang ada terlebih di Indonesia atau bisa 
dikatakan persepsi masyarakat tentang ketimpangan gender terhadap perempuan telah dipengaruhi oleh konstruksi sosial hal tersebut dikarenakan budaya di Indonesia sedari nenek moyang dahulu memang selalu mengunggulkan dan menguntungkan kaum laki - laki oleh karena itu persepsi ketimpangan gender terhadap perempuan sangat membentuk mind set masyarakat Indonesia yang naasnya lagi persepsi tersebut terus mempengaruhi pikiran kita dari tahun ketahunnya atau secara turun temurun. Menurut Oakley menjadi Ibu bukanlah kodrat perempuan namun menjadi Ibu adalah serangkaian sosialisasi yang diterima oleh anakanak perempuan, hingga kini masih banyak media yang menayangkan perempuan-perempuan Indonesia dengan segenap ke-sexis-annya, tak heran jika hegemoni tersebut melekat pada konstruksi pikiran perempuan-perempuan Indonesia hingga saat ini, penegakkan hak asasai manusia dan hak asasi perempuan tak akan mencapai ekspektasi jika keadilan dan kesetaraan gender tidak bisa diwujudkan.

Jika dilihat dari Undang-Undang No. 7 Tahun 1984 mengenai penghapusan segala bentuk diskriminasi terhadap wanita (CEDAW) dukungan Pemerintah RI terhadap tujuan Konvensi Mengenai Penghapusan Segala Bentuk Diskriminasi Terhadap Wanita (Konvensi Wanita) yang dikemukan dalam keterangan Pemerintah di DPR Jakarta, 27 Februari 1984 antara lain menghapuskan diskriminasi dalam segala bentuk-bentuknya terhadap wanita dan mungkin dalam terwujudnya prinsip-prinsip persamaan hak bagi wanitadi bidang politik, hukum, ekonomi, dan sosial budaya.

Yang menjadi pertayaan adalah "Masih konsistensikan pemerintah RI terhadap tujuan tersebut hingga kini? Untuk menjawab pertanyaan tersebut, harus diketahui terlebih dahulu apakah pengertian "Diskriminasi" yang dimaksud dalam Konvensi tersebut?

Pasal 1 : Untuk tujuan Konvensi yang sekarang ini, istilah "DISKRIMINASI TERHADAP WANITA" berarti setiap pembedaan, pengucilan, atau pembatasan yang dibuat atas dasar jenis kelamin, yang mempunyai pengaruh atau tujuan untuk mengurangi atau menghapuskan pengakuan, penikmatan atau penggunaan hak-hak asasi manusia dan kebebasan-kebebasan pokok dibidang politik, ekonomi, sosial, budaya, sipil atau apapun lainnya oleh kaum wanita, terlepas dari status perkawinan mereka, atas dasar persamaan antara pria dan wanita.

Konvensi Wanita secara konkrit menekankan :

a. Kesetaraan dan keadilan antara Perempuan dan Laki-laki (genderequality and equity),

b. persamaan hak dan kesempatan serta perlakukan adil disegala bidang dalam semua kegiatan meskipun diakui adanya perbedaan: (a) Perbedaan biologi/kodrati antara perempuan dan laki-laki. (b) Perbedaan perlakuan terhadap perempuan berdasarkan gender dengan akibat dimana perempuan dirugikan: perempuan sebagai subordinasi lakilaki baik dalam keluarga maupun masyarakat, pembatasan kemampuan dan kesempatan untuk memanfaatkan peluang yang ada untuk tumbuh berkembang secara optimal, menyeluruh dan terpadu Peluang untuk berperan dalam pembangunan dan menikmati hasil pembangunan.

c. Perbedaan kondisi dan posisi perempuan terhadap laki-Iaki dimana perempuan berada dalam kondisi dan posisi yang lemah karena sejak semula sudah dipolakan adanya diskriminasi dalam budaya adat atau karena lingkungan keluarga, masyarakat yang tidak mendukung adanya kesetaraan dan kemandirian perempuan.

d. Prinsip dasar dari Konvensi Wanita yang kita buat yaitu :

- Prinsip persamaan substantif

- Prinsip non diskriminasi

- Prinsip kewajiban negara.

\section{Prinsip Persamaan Subtantif.}


Prinsip Persamaan Substantif meliputi : pendekatan yang terdiri atas langkah-langkah khusus agar perempuan mempunyai akses yang sama dan dapat menikmati manfaat yang sama dengan laki-laki terhadap kesempatan dan peluang yang ada.

Contoh: secara formal ditetapkan serta berasumsi perempuan dan laki-laki adalah sama, dengan akibat harus diperlakukan sama dan mempunyai kesempatan yang sama serta masing-masing akan melaksanakan kinerja yang sama pula, namun faktanya tidak demikian. Misalnya: kesempatan kerja malam hari bagi laki-laki dan perempuan adalah sama secara de jure, ternyata bagi perempuan belum tentu dapat memanfaatkan kesempatan kerja malam tersebut, karena harus menghadapi lingkungan sosial yang tidak sama, sebab fakta dalam masyarakat mengkondisikan bahwa perempuan tidak pada tempatnya bekerja diluar rumah pada malam hari karena menghindari pelecehan atau keadaan tidak aman bagi dirinya, sehingga perempuan kalau harus keluar rumah pada waktu malam untuk bekerja akan menanggung resiko sendiri bila terjadi sesuatu terhadap dirinya. Oleh karena itu diperlukan pendekatan koreksi dimana perusahaan harus menyediakan transportasi antar jemput bagi pegawai perempuan, hal ini biasanya akan menambah pengeluaran (budget) perusahaan, maka lebih baik perusahaan tidak menerima pegawai perempuan.

Langkah-langkah untuk merealisasikan hak perempuan ialah dengan menghapus adanya perbedaan, disparitas/kesenjangan atau keadaan yang merugikan perempuan misalkan: keharusan adanya perubahan pola pikir dan tingkah laku sosial budaya terhadap perempuan, menghapuskan prasangka serta kebiasaan dan praktek yang bersifat diskriminatif (untuk tidak mengganggu perempuan yang jalan sendiri di malam hari). Kewajiban Pemerintah untuk mengembangkan kebijaksanaan dan peraturan berkaitan dengan langkah-langkah yang diperlukan untuk mencapai persamaan substantif, hak yang sama dan persamaan legal standardantara laki-laki dan perempuan (misalnya; hak yang sama dalam keluarga, peluang kerja yang sama, pemberian gaji yang sama, kewarisan, kewarganegaraan, kesempatan di bidang politik).

\section{Prinsip Non Diskriminasi}

Selain sudah jelas apa pengertian diskriminasi dalam Pasal 1 , dapat disimak dalam pasal 4, bahwa yang tidak dianggap diskriminasi ialah tindakan yang disebut afirmative action yaitu tindakan khusus yang bersifat sementara dengan tujuan untuk mendapatkan persamaan kesempatan dan perlakuan sama yang nyata antara perempuan dan laki-Iaki. Misalnya : perlindungan kehamilan bagi perempuan (cuti hamil, cuti haid) hal ini tidak dapat dianggap sebagai pemberian kesempatan yang diskriminatif bagi pekerja laki-laki.

\section{Prinsip Kewajiban Negara}

Menjamin hak-hak perempuan di bidang hukum dan kebijaksanaan serta jaminan kepada perempuan agar dapat menikmati hasil pelaksananya. Negara tidak saja wajib menjamin persamaan hak secara de jure (substansi hukumnya) tetapi juga dari segi de facto yaitu dengan mendorong realisasi terwujudnya hak perempuan (Pasal 2)

Misalnya: mencabut/mengamandir peraturan, kebijaksanaan, kekuasaan praktek yang diskriminatif terhadap perempuan dan mengadakan pembaharuan-pembaharuan yang sensitif gender.

Secara ringkas kewajiban negara meliputi: mencegah diskriminasi terhadap perempuan, melarang diskriminasi perempuan, melakukan identifikasi adanya diskriminasi terhadap perempuan dan menjalankan langkah-langkah untuk mengatasinya, melaksanakan sanksi atas tindakan diskriminatif terhadap perempuan, memberikan dukungan pada penegakan hak-hak perempuan dan mendorong persamaan, kesetaraan dan keadilan melalul langkah proaktif, dan meningkatkan persamaan de facto perempuan dan laki-Iaki.

Rincian yang ada dalam konvensi menggambarkan bahwa perubahan sosial budaya dan ekonomi serta politik harus terjadi dan diwujudkan dalam hampir semua penghidupan 
yang berarti merubah peraturan termasuk mengubah pola tingkah laku yang semula diskriminatif yang telah lama dilegitimasi oleh adat dan budaya menuju pola kesetaraan dan keadilan gender. Untuk memberdayakan perempuan, sumber daya manusia adalah faktor penting yang perlu ditingkatkan.

Penutup

Penelitian dengan participatory action research (PAR) dalam rangka penguatan ekonomi kreatif keluarga kesenian jaranan dan bantengan trah kanjuruan Kelurahan Tlogomas Kota Malang. Hasil forum group discussion dapat dikatakan bahwa wanita menjadi korban budaya, sehingga tidak hanya persepsi masyarakat, namun dalam kasus ini wanita menjadi objek dalam kesenian. Peranan keluarga harus menjadi solid dikala perempuan yang menjadi objek kesenian perlu tangungjawab dan kepedulian semua pihak. Pemerintah yang telah mengeluarkan Undang-Undang atas perempuan seharusnya membantu bagaimana memberdayakan keluarga agar perekonomia keluarga menjadi tetap hidup dan seimbang.

\section{Daftar Pustaka}

Amir Abadi Jusuf, Salemba Empat, Jakarta, 2002.

Bodnar, H. George dan William S. Hopwood, Sistem Informasi Akuntansi, Buku I, Edisi Ke6, Penerjemah Amir Abadi Jusuf dan Rudi M. Tambunan, Salemba Empat, Jakarta, 2000.

Depkop. 2012. Statistik Usaha Kecil dan Menengah Tahun 2011-2012 diakses dari http://www.depkop.go.id

Dipta, I Wayan.. 2011. Model Pengembangan Wirausaha. Infokop Volume 19 - Juli 201: 53 $-66$

Gunawan Sumodiningrat, (2007). Peranan Lembaga Keuangan Mikro

Hall, A. James, Sistem Informasi Akuntansi, Buku 2, Edisi ke-1, Penerjemah

Haryono Yusuf, AL, Dasar-dasar Akuntansi, Jilid 2 , Bagian Penerbitan AA YKPN, Yogyakarta, 2007

.Hasan, I. 2011. Penguatan Kompetensi Kewirausahaan Dan Daya Saing UKM Komoditi Unggulan Ekspor Di Provinsi Aceh. Infokop Volume, 19 - JULI 2011: 38 - 52.

Jogiyanto. Sistem Informasi Berbasis Komputer. Edisi 2. Penerbit BPFE Yogyakarta. 2000

Joewono, H. 2011. Strategi Pengembangan Kewirausahaan Nasional : Sebuah Rekomendasi Operasional. Infokop Volume 19 - Juli 2011 : 1 - 23.

Kementerian Negara Koperasi dan UKM. 2008. Undang-Undang Republik Indonesia Nomor 20 Tahun 2008 Tentang Usaha Mikro Kecil dan Menengah. Kementerian Negara KUKM R.I. Jakarta.

Mulyadi, Akuntansi Biaya, Cetakan III,Ed.5. Bagian Penerbitan STIE YKPN, Yogyakarta, 2003

Mantle, Jonathan. 2008. Companies That Changed the World. Quercus Publishing Ltd, 21 Bloomsbury Square, London.

Peraturan Pemerintah No. 36 Tahun 2013, Tentang pajak untuk usaha dengan penghasilan dibawah 4,8 Milyar.

Setyobudi, L., 2011. Metode COBLAS (Consulting Based Learning for ASEAN SMEs) untuk Pendidikan Entrepreneurship di Perguruan Tinggi. Infokop Volume 19 - Juli 2011: 24 - 37.

Setyobudi, L., T. Ohe, dan P. Chanming. 2011. Pendidikan Entrepreneurship: Pembelajaran Berbasis Konsultan Untuk Fasilitator (COBLAS Fasilitator). Petunjuk untuk Dosen. Universitas Brawijaya Press. (in print). 
Sijabat, S. 2011. Dampak Penerapan Undang-Undang Nomor 20 Tahun 2008 Tentang Umkm Terhadap Pengembangan Kewirausahaan Bagi UMKM. Infokop Volume 19 - Juli 2011: 86 - 103

Undang-Undang No. 7 Tahun 1984 tentang konvensi mengenai penghapusan segala bentuk diskriminasi terhadap wanita (CEDAW)

Wijayanti, A. dan Kartika Hendra Ts. 2012. Development of Small and Medium Enterprises (SMEs) Accounting Information System in Cluster of Kampung Laweyan Batik, Surakarta, Indonesia. Chinese Business Review, ISSN 1537-1506. October 2013, Vol. 12, No. 10, 698-711. 